
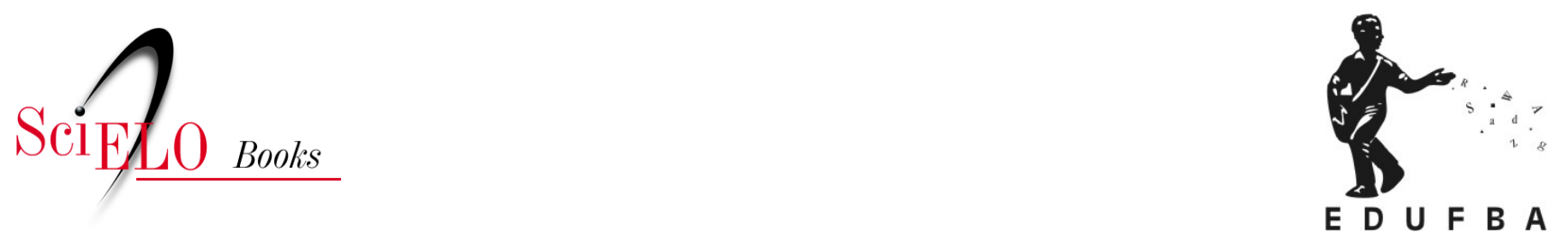

\title{
Reflexões \\ Jornada de Literatura de Passo Fundo arrebenta
}

\author{
Nelson De Luca Pretto
}

PRETTO, N.D.L. Jornada de Literatura de Passo Fundo arrebenta. In: Educações, culturas e hackers: escritos e reflexões [online]. Salvador: EDUFBA, 2017, pp. 126-128. ISBN: 978-85-232-2019-8.

https://doi.org/10.7476/9788523220198.0024.

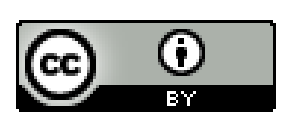

All the contents of this work, except where otherwise noted, is licensed under a Creative Commons Attribution $\underline{4.0 \text { International license. }}$

Todo o conteúdo deste trabalho, exceto quando houver ressalva, é publicado sob a licença Creative Commons Atribição 4.0.

Todo el contenido de esta obra, excepto donde se indique lo contrario, está bajo licencia de la licencia $\underline{\text { Creative }}$ Commons Reconocimento 4.0. 


\section{Jornada de Literatura de Passo Fundo arrebenta}

"A cultura venceu o futebol" foi o grito de guerra lançado pela lutadora Tânia Mariza Kuchenbecker Rosing, professora da Universidade de Passo Fundo, na abertura de 15a Jornada Nacional de Literatura. Isto em função da dificuldade em conseguir concretizar a Jornada desse ano em função da concorrência na captação de recursos com a Copa das Confederações. Parece incrível, mas essa é a realidade dos financiamentos públicos nos dias de hoje: para a Copa tudo, verbas, leis especiais, definições externas até sobre o nosso cotidiano nos estádios, arredores e muito mais. Para as demais demandas, um sofrimento terrível. Mas a luta foi grande e a Jornada está de pé, mais uma vez. São mais de 30 anos de luta na organização para a promoção da literatura e da leitura no país.

Vinte e oito mil inscritos circulam pelas tendas e pelo centro de eventos da Universidade de Passo Fundo, durante os cinco dias do evento. O tema Leituras Jovens do Mundo fez jus à programação: a meninada das escolas de Passo Fundo e dos municípios da região vizinha esteve presente em peso, sob o olhar atento de suas professoras.

$\mathrm{O}$ frio da região, em alguns momentos com dois graus negativos, não assustou ninguém. A tenda principal abrigou milhares de pessoas para acompanhar atentos Ignacio de Loyola Brandão, Luciana Savaget, Ana Maria Machado, Miriam Goldemberg, Laura Muler, Walcyr Carrasco, Roberto da Matta, entre tantos outros brasileiros, portugueses, espanhóis, mexicanos e argentinos. E, juntos com estes, ainda Kleiton \& Kleidir, Emicida e o Afro Reggae dando um show a parte. Um verdadeiro Portal das Linguagens, como foi denominado todo o complexo de enormes tendas, salas de aula, auditórios e centro de convenções da Universidade de Passo Fundo. À noite, a JorNight arrebata com shows e mais shows num misto de arte, cultura, diversão e muita alegria.

A atualidade da Jornada é fantástica, não só pela temática - Leituras Jovens do Mundo -, como pelo modelo de evento que incentiva a leitura 
e escrita, considerando todos os suportes. Mais do que isso, a preparação das crianças e jovens da região acontece muito antes nas escolas públicas, onde professoras animadas leem com seus alunos os autores, presentes em carne e osso durante a Jornada propriamente dita. O que se quer é "construir o presente e o futuro pela leitura”, como afirmou Tânia na abertura. Para tal, outras escritas em outros suportes também foram consideradas e fiquei encantado com a ideia de se instalar uma Escola de Hackers, espaço privilegiado da feira, onde a turma jovem comparecia para aprender a programar computadores, utilizando a linguagem Scratch, ao lado de uma oficina de robótica, onde a piazada ficava de olhos reluzentes ao construir e fazer andar os pequenos e grandes objetos-geringonças que se moviam a partir de programinhas e mecânicas desenvolvidos ali mesmo.

Uma jornada aberta às novidades tecnológicas contemporâneas e, com isso, certamente, sintonizada com os jovens leitores e escritores.

O esforço e o grande apoio da Prefeitura de Passo Fundo foram fundamentais, com aporte de recursos, mas também com o estímulo e as condições para o pleno envolvimento de todo o sistema educacional. Além disso, na mesma linha, a prefeitura anunciou, logo no primeiro dia, a construção de mais 35 bibliotecas públicas no município, sendo que 30 delas como fruto da transformação das bibliotecas escolares em bibliotecas públicas, com acesso livre para toda a população.

Foi de fato uma semana muito rica e que me possibilitou grandes encontros e emoções. Na tenda principal, acompanhei com júbilo a apresentação de Ignácio Loyola Brandão e sua filha Rita Gullo, apresentando Solidão no fundo da agulha, um livro e CD, onde ele conta algumas de suas histórias tendo como referência as músicas que lhe marcaram ao longo da vida, desde a sua infância em Araraquara/SP, que, no espetáculo e no CD que acompanha o livro, são interpretadas deliciosamente por ela. Foi uma maravilha ouvi-los e, já com o livro na mão, sorver essas maravilhosas histórias, embaladas pela música.

Muitas outras histórias tomaram conta de mim essa semana. Uma delas me pegou navegando nas redes sociais e, ao ver a página da Jornada no Facebook, leio a postagem de uma pessoa que não conheço, chamada Vó Dina. Suas palavras: "meu neto chegou em casa todo entusiasmado, 
dizendo que foi o melhor evento que assistiu. Nos seus dez anos de vida nunca o vi tão maravilhado com alguma coisa. Parabéns a quem tanto já trabalhou pelo incentivo à leitura."

Dez anos e maravilhado com a leitura, quer coisa melhor para um educador?

Saio de Passo Fundo literalmente renovado e com a alma lavada, por uma inundação de cultura e generosidade.

Vida longa para a Jornada Nacional de Literatura de Passo Fundo e que ela estimule outras universidades e prefeituras desse enorme Brasil a seguir o seu exemplo.

Publicado na revista digital Terra Magazine, São Paulo, em 2 de fevereiro de 2013.

\section{A leitura está de luto}

A notícia correu veloz e mobiliza muita gente: a Jornada Nacional de Literatura de Passo Fundo foi cancelada.

A reação de escritores, intelectuais, professores, jovens e crianças, de lá e de cá, foi de indignação. É inacreditável que um evento da magnitude da Jornada seja cancelado, mesmo em tempo de crise. Nesses momentos, lamentavelmente, sempre quem mais sofre é a cultura, considerada que é um artigo supérfluo, um mero adorno.

Estive na última jornada, em uma atividade no palco principal, instalado em uma enorme tenda, com dezenas de milhares de pessoas (inscreveram-se naquela Jornada 35 mil pessoas!). Estava junto com o espanhol Cesar Coll, o português J. Antonio Furtado e o italiano Massimo Canevacci, sob a batuta de Ignacio de Loyola Brandão e Luciana Savaget, 